\title{
Further Studies on Lipid-Chemical Differences Between Cancerous and Adenomatous Polypous Tissues in the Human Large Intestine
}

\author{
Ichiro Nakazawa, Shoichi Yamagata and Hikaru Watanabe \\ The Third Department of Internal Medicine, Tohoku University \\ School of Medicine, Sendai
}

\begin{abstract}
Nakazawa, I., Yamagata, S. and Watanabe, H. Further Studies on LipidChemical Differences between Cancerous and Adenomatous Polypous Tissues in the Human Large Intestine. Tohoku J. exp. Med., 1976, 118 (Suppl.), 117-125 17 cases of cancer and 18 cases of adenomatous polyp in the large intestine were subjected to lipid-chemical studies of their tissues in order to clarify the biochemical differences between malignant neoplastic growth and benign growth. Cancerous and adenomatous polypous tissues were collected by biopsy or surgical operation together with the respective control tissues. One part of the total lipid extracted from each tissue was separated into triglyceride and phospholipid fraction by a thin-layer chromatography (TLC). The fatty acid composition and content of each lipid fraction were measured by a gas-liquid chromatography (GLC). When the fatty acid composition of phospholipid was expressed in terms of the deviation rate, that of $\mathrm{C}_{14: 0}$ was remarkably increased and that of $\mathrm{C}_{20: 4}$ was remarkably decreased in the cancerous cases as compared with the respective values of the cases of adenomatous polyp. More definite differences were recognized between the cancerous cases and the cases of adenomatous polyp, when the ratio of the deviation rate of $\mathrm{C}_{14: 0}$ to that of $\mathrm{C}_{20: 4}$ was calculated in each case. Namely, the ratios distributed between 2.064 and 4.125 in 10 cancerous cases, and between 0.393 and 1.856 in 16 cases of adenomatous polyp, indicating the biochemical differences between cancerous tissues and adenomatous polypous tissues. - phospholipid; cancer; polyp; growth; human large intestine
\end{abstract}

At present, our knowledge about cancer is chiefly based on its morphologic features. For example, it is hard to define cancer from the standpoint of biochemistry, although many kinds of biochemical approach to cancer have been tried. However, it would be indispensable to clarify the biochemical features of cancer in order to establish a really effective chemotherapy against cancer. In this respect, it is quite important to clarify biochemical differences between malignant neoplastic growth and benign growth of human tissues. In the human large intestine, the cancerous tissue belongs to a group of malignant growth, and the adenomatous polypous tissue belongs to that of benign growth which has been considered to be precancerous. Nakazawa et al. $(1973$, 1974) reported lipidchemical differences between human cancerous tissues and adenomatous polypous

Received for publication, November 20, 1975.

Abbreviations: The fatty acids are designated by chain length and number of double bond. For example, $\mathrm{C}_{20: 4}$ stands for a fatty acid with 20 carbon atoms and 4 double bonds. 
tissues in the large intestine, using an idea of the deviation rate. The present report deals with further studies on lipid-chemical differences between cancerous and adenomatous polypous tissues in the human large intestine.

\section{Materials and Methods}

Tissues. From 17 cases of cancer and 18 cases of adenomatous polyp in the large intestine, the tissues of the lesions and the normal tissues surrounding the lesions were collected. In 17 cancerous cases, the tissues of 8 cases were collected by biopsy under endoseopic examination and the tissues of 9 cases excised by surgical operation. In 18 cases of adenomatous polyp, the tissues of 13 cases were collected by biopsy under romanoscopy or fiber-colonoscopy and tissues of 5 cases were taken by surgical operation. The methods of biopsy and endoscopy were reported by Watanabe et al. (1972). All cases used in this report were diagnosed histopathologically. Adenomatous polypous tissues were classified into two types according to their histologic features, namely, the group in which the epithelium is similar to that of metaplastic polyp described by Morson (1962) and the group of ordinary adenomatous polyp. Cases No. 1 and No. 2 belonged to the former group and the other cases belonged to the latter group as shown in Tables 2, 5 and 6. The histologic feature of cancerous tissues was adenocarcinoma.

Chemicals. All organic solvents were redistilled. Silica-Gel-G nach Stahl for a thinlayer chromatography (TLC) was purchased from Merk Chemical Company (Germany). Standards for a gas liquid chromatography (GLG) were obtained from Applied Science Laboratories, Inc., State College, Pennsylvania, USA. Other chemicals used were obtained commercially and were of extra-pure grade.

Extraction and chromatography. Each tissue collected was homogenized after weighing with methanol-chloroform $(1: 2 \mathrm{v} / \mathrm{v})$ by a Potter type glass homogenizer at room temperature, and the total lipid was extracted by the method of Folch et al. (1957). The homogenate was filtered and dried up in $\mathrm{N}_{2}$ gas under a reduced pressure, and redissolved with methanol-chloroform. When the tissues weighing more than $15 \mathrm{mg}$ were employed, the solution was divided into two precisely measured parts and each was used for the analysis of the total lipid and lipid fractionation by TLC. TLC was performed by the methods of Vogel et al. (1962), using a mixture of petroleum ether, diethylether and acetic acid $(90: 10: 1 \mathrm{v} / \mathrm{v})$ as a developing solvent. Each lipid fraction was scraped off the plate and saponified by $10 \% \mathrm{KOH}$ methanol at $37^{\circ} \mathrm{C}$ for $48 \mathrm{hr}$. Then, the fatty acids of each lipid fraction were extracted and methylated by diazomethane. Before applying to GLC, a definite quantity of methyl erucate was added to the samples as an internal standard.

Further details of the methods for TLC and GLC analyses were described previously (Nakazawa et al. 1973).

\section{Results}

As discussed in the previous report (Nakazawa et al. 1973), it is important in the lipid-chemical study of human morbid tissues to have tissues which are adequate as the control. The best control tissue would be the respective normal tissue surrounding the lesion. Our data shown in the following are based on this conception.

Fatty acid content of the total lipid. In 10 out of 14 cancerous cases, the fatty acid content of the total lipid in the lesion was decreased as compared with that of the respective non-cancerous tissue surrounding the lesion. However, in 4 cases out of 5 adenomatous polypous cases, the fatty acid content of the total 
TABLE 1. Contents and ratio of phospholipid and triglyceride fatty acids in cancerous tissues of the human large intestine

\begin{tabular}{|c|c|c|c|c|c|}
\hline \multirow[b]{2}{*}{$\begin{array}{l}\text { Case } \\
\text { No. }\end{array}$} & \multirow[b]{2}{*}{ Diagnosis } & \multirow[b]{2}{*}{ Tissue } & \multicolumn{3}{|c|}{ Fatty acid content* } \\
\hline & & & $\begin{array}{l}\text { Phospholipd } \\
\text { (mg) }\end{array}$ & $\begin{array}{l}\text { Triglyceride } \\
\text { (mg) }\end{array}$ & Ratio $†$ \\
\hline \multirow[t]{2}{*}{1} & \multirow{2}{*}{ Rectal cancer } & Cancerous & 7. 291 & 2.485 & 2.934 \\
\hline & & Non-cancerous & 5. 995 & 3.241 & 1.850 \\
\hline \multirow{2}{*}{2} & \multirow{2}{*}{ Rectal cancer } & Cancerous & 4.265 & 0.469 & 9.094 \\
\hline & & Non-cancerous & 7. 141 & 3.063 & 2. 331 \\
\hline \multirow{2}{*}{3} & \multirow{2}{*}{ Caecal cancer } & Cancerous & 3.984 & 0.650 & 6.129 \\
\hline & & Non-cancerous & 3.341 & 1.591 & 2.100 \\
\hline \multirow{2}{*}{4} & \multirow{2}{*}{ Colonic cancer } & Cancerous & 3. 938 & 0.412 & 9.558 \\
\hline & & Non-cancerous & 4.727 & 5.497 & 0.860 \\
\hline \multirow{2}{*}{5} & \multirow{2}{*}{ Rectal cancer } & Cancerous & 6.181 & 0.511 & 11.218 \\
\hline & & Non-cancerous & 3. 640 & 3.089 & 1.178 \\
\hline \multirow{2}{*}{6} & \multirow{2}{*}{ Colonic cancer } & Cancerous & 4. 301 & 1. 039 & 4. 140 \\
\hline & & Non-cancerous & 5.836 & 1. 656 & 3.524 \\
\hline \multirow{2}{*}{7} & \multirow{2}{*}{ Colonic cancer } & Cancerous & 3. 661 & 0.570 & 6.422 \\
\hline & & Non-cancerous & 4.285 & 1.070 & 4.005 \\
\hline \multirow[b]{2}{*}{8} & \multirow{2}{*}{ Colonic cancer } & Cancerous & 2.161 & 0.244 & 8.857 \\
\hline & & Non-cancerous & 3.528 & 0.797 & 4.427 \\
\hline \multirow{2}{*}{9} & \multirow{2}{*}{ Rectal cancer } & Cancerous & 3. 090 & 0.488 & 6.332 \\
\hline & & Non-cancerous & 4.248 & 0.904 & 4.699 \\
\hline \multirow{2}{*}{10} & \multirow{2}{*}{ Rectal cancer } & Cancerous & 3. 710 & 0.259 & 14.324 \\
\hline & & Non-cancerous & 2. 852 & 4.962 & 0.575 \\
\hline
\end{tabular}

* In mg per $1 \mathrm{~g}$ of wet tissue.

$\dagger$ Ratio of the phospholipid fatty acid content to the triglyceride fatty acid content.

lipid in the lesion was increased as compared with that of the control tissue.

Fatty acid content of phospholipid. In 4 of 10 cancerous cases, the fatty acid content of the phospholipid in the morbid tissue was larger than the respective control tissue, as shown in Table 1 . In 10 of 14 cases of adenomatous polyp, the fatty acid content of the phospholipid in the lesion was larger than the respective control tissue, as shown in Table 2.

Fatty acid content of triglyceride. As shown in Table 1, in all of 10 cancerous cases the fatty acid content of triglyceride in the lesion was smaller than that of the respective control tissue. In 13 of 14 cases of adenomatous polyp, the fatty acid content of the morbid tissue was smaller than that of the respective control tissue, as shown in Table 2.

Fatty acid composition of each lipid fraction. The fatty acid composition of each lipid fraction was shown in the form of the deviation rate (DR) in the 
TABLE 2. Contents and ratio of phosphclipid and triglyceride fatty acids in adenomatous polypous tissues

\begin{tabular}{|c|c|c|c|c|c|}
\hline \multirow[b]{2}{*}{$\begin{array}{l}\text { Case } \\
\text { No. }\end{array}$} & \multirow[b]{2}{*}{ Diagnosis } & \multirow[b]{2}{*}{ Tissue } & \multicolumn{3}{|c|}{ Fatty acid content* } \\
\hline & & & $\begin{array}{l}\text { Phospholipid } \\
\text { (mg) }\end{array}$ & $\begin{array}{l}\text { Triglyceride } \\
\text { (mg) }\end{array}$ & Ratio $†$ \\
\hline 1 & $\begin{array}{l}\text { Rectal adenom. } \\
\text { atous polyp }\end{array}$ & $\begin{array}{l}\text { Polypous } \\
\text { Normal }\end{array}$ & $\begin{array}{l}5.133 \\
3.997\end{array}$ & $\begin{array}{l}0.779 \\
2.578\end{array}$ & $\begin{array}{l}6.585 \\
1.550\end{array}$ \\
\hline 2 & $\begin{array}{l}\text { Rectal adenom- } \\
\text { atous polyp }\end{array}$ & $\begin{array}{l}\text { Polypous } \\
\text { Normal }\end{array}$ & $\begin{array}{r}10.414 \\
6.830\end{array}$ & $\begin{array}{l}2.112 \\
7.237\end{array}$ & $\begin{array}{l}4.931 \\
0.944\end{array}$ \\
\hline 3 & $\begin{array}{l}\text { Rectal adenom- } \\
\text { atous polyp }\end{array}$ & $\begin{array}{l}\text { Polypous } \\
\text { Normal }\end{array}$ & $\begin{array}{l}5.565 \\
3.159\end{array}$ & $\begin{array}{l}0.191 \\
0.916\end{array}$ & $\begin{array}{r}29.136 \\
3.449\end{array}$ \\
\hline 4 & $\begin{array}{l}\text { Colonic adenom- } \\
\text { atous polyp }\end{array}$ & $\begin{array}{l}\text { Polypous } \\
\text { Normal }\end{array}$ & $\begin{array}{l}8.963 \\
5.731\end{array}$ & $\begin{array}{l}0.350 \\
3.506\end{array}$ & $\begin{array}{r}12.804 \\
1.635\end{array}$ \\
\hline 5 & $\begin{array}{l}\text { Colonic adenom- } \\
\text { atous polyp }\end{array}$ & $\begin{array}{l}\text { Polypous } \\
\text { Normal }\end{array}$ & $\begin{array}{l}5.251 \\
6.491\end{array}$ & $\begin{array}{l}0.546 \\
2.047\end{array}$ & $\begin{array}{l}9.617 \\
3.171\end{array}$ \\
\hline 6 & $\begin{array}{l}\text { Colonic adenom. } \\
\text { atous polyp }\end{array}$ & $\begin{array}{l}\text { Polypous } \\
\text { Normal }\end{array}$ & $\begin{array}{l}6.088 \\
7.083\end{array}$ & $\begin{array}{l}0.885 \\
1.092\end{array}$ & $\begin{array}{l}6.879 \\
6.486\end{array}$ \\
\hline & $\begin{array}{l}\text { Colonic adenom- } \\
\text { atous polyp }\end{array}$ & $\begin{array}{l}\text { Polypous } \\
\text { Normal }\end{array}$ & $\begin{array}{l}6.422 \\
5.201\end{array}$ & $\begin{array}{l}0.523 \\
6.862\end{array}$ & $\begin{array}{r}14.399 \\
0.758\end{array}$ \\
\hline 8 & $\begin{array}{l}\text { Colonic adenom - } \\
\text { atous polyp }\end{array}$ & $\begin{array}{l}\text { Polypous } \\
\text { Normal }\end{array}$ & $\begin{array}{l}8.771 \\
3.568\end{array}$ & $\begin{array}{l}3.959 \\
1.884\end{array}$ & $\begin{array}{l}2.215 \\
1.894\end{array}$ \\
\hline 9 & $\begin{array}{l}\text { Colonic adenom- } \\
\text { atous polyp }\end{array}$ & $\begin{array}{l}\text { Polypous } \\
\text { Normal }\end{array}$ & $\begin{array}{l}5.397 \\
4.633\end{array}$ & $\begin{array}{l}0.744 \\
2.952\end{array}$ & $\begin{array}{l}7.254 \\
1.569\end{array}$ \\
\hline 10 & $\begin{array}{l}\text { Colonic adenom- } \\
\text { atous polyp }\end{array}$ & $\begin{array}{l}\text { Polypous } \\
\text { Normal }\end{array}$ & $\begin{array}{l}1.408 \\
3.880\end{array}$ & $\begin{array}{l}0.456 \\
1.604\end{array}$ & $\begin{array}{l}3.088 \\
2.419\end{array}$ \\
\hline 11 & $\begin{array}{l}\text { Rectal adenom- } \\
\text { atous polyp }\end{array}$ & $\begin{array}{l}\text { Polypous } \\
\text { Normal }\end{array}$ & $\begin{array}{l}3.993 \\
3.679\end{array}$ & $\begin{array}{l}0.632 \\
1.524\end{array}$ & $\begin{array}{l}6.318 \\
2.414\end{array}$ \\
\hline 12 & $\begin{array}{l}\text { Rectal adenom- } \\
\text { atous polyp }\end{array}$ & $\begin{array}{l}\text { Polypous } \\
\text { Normal }\end{array}$ & $\begin{array}{l}5.979 \\
5.345\end{array}$ & $\begin{array}{l}0.428 \\
0.817\end{array}$ & $\begin{array}{r}13.970 \\
6.542\end{array}$ \\
\hline 13 & $\begin{array}{l}\text { Rectal adenom- } \\
\text { atous polyp }\end{array}$ & $\begin{array}{l}\text { Polypous } \\
\text { Normal }\end{array}$ & $\begin{array}{l}6.965 \\
3.664\end{array}$ & $\begin{array}{r}0.326 \\
13.219\end{array}$ & $\begin{array}{r}21.365 \\
0.277\end{array}$ \\
\hline 14 & $\begin{array}{l}\text { Colonic adenom- } \\
\text { atous polyp }\end{array}$ & $\begin{array}{l}\text { Polypous } \\
\text { Normal }\end{array}$ & $\begin{array}{l}3.645 \\
4.123\end{array}$ & $\begin{array}{l}0.196 \\
0.510\end{array}$ & $\begin{array}{r}18.579 \\
8.084\end{array}$ \\
\hline
\end{tabular}

* In mg per $1 \mathrm{~g}$ of wet tissue.

$\uparrow$ Ratio of phospholipid fatty acid content to triglyceride fatty acid content.

following tables, for the convenience of easier comparison between cancer and adenomatous polyp.

The deviation rate (DR) was calculated by the following formula:

$$
\mathrm{DR}=-\frac{\text { Percentage value of the fatty acid in the morbid tissue }}{\text { Percentage value of the fatty acid in the control tissue }} .
$$


TABLE 3. The fatty acid composition of the total lipid in terms of deviation rate

\begin{tabular}{ccc}
\hline & \multicolumn{2}{c}{ Deviation rate } \\
\cline { 2 - 3 } Fatty acid & Cancer* & Adenomatous polyp $\dagger$ \\
\hline $\mathrm{C}_{14: 0}$ & 1.009 & 0.639 \\
$\mathrm{C}_{16: 0}$ & 0.894 & 0.982 \\
$\mathrm{C}_{16: 1}$ & 1.070 & 0.815 \\
$\mathrm{C}_{18: 0}$ & 1.430 & 1.068 \\
$\mathrm{C}_{18: 1}$ & 0.953 & 0.882 \\
$\mathrm{C}_{18: 2}$ & 0.901 & 1.092 \\
$\mathrm{C}_{20: 4}$ & 1.251 & 1.075 \\
$\mathrm{C}_{22: 6}$ & 1.239 & 1.427 \\
\hline
\end{tabular}

* Mean of 12 cases. $†$ Mean of 6 cases.

TABLE 4. The phospholipid fatty acid composition of colonic, caecal and rectal lesions in terms of deviation rate

\begin{tabular}{|c|c|c|c|c|c|c|c|c|c|}
\hline \multirow{2}{*}{$\begin{array}{l}\text { Case } \\
\text { No. }\end{array}$} & \multirow{2}{*}{ Diagnosis } & \multicolumn{7}{|c|}{ Deviation rate } & \multirow{2}{*}{$\begin{array}{l}\text { Ratio of DR } \\
\mathrm{C}_{14: 0} / \mathrm{C}_{20: 4}\end{array}$} \\
\hline & & $\mathrm{C}_{14: 0}$ & $\mathrm{C}_{16: 0}$ & $\mathrm{C}_{16: 1}$ & $\mathrm{C}_{18: 0}$ & $\mathrm{C}_{18: 1}$ & $\mathrm{C}_{18: 2}$ & $\mathrm{C}_{20: 4}$ & \\
\hline 1 & Rectal cancer & 2. 636 & 0.865 & 0.971 & 1.409 & 1.031 & 1.159 & 0.642 & 4.106 \\
\hline 2 & Rectal cancer & 1.922 & 1. 007 & 2. 248 & 0.906 & 0.967 & 0.954 & 0.601 & 3. 198 \\
\hline 3 & Caecal cancer & 1. 607 & 0.855 & 1. 820 & 1. 271 & 1.250 & 0.776 & 0.566 & 2.839 \\
\hline 4 & Colonic cancer & 2.846 & 1.084 & 2.086 & 0.884 & 0.994 & 0.957 & 0.723 & 3. 936 \\
\hline 5 & Rectal cancer & 2.171 & 1. 037 & 1.599 & 0.983 & 0.990 & 0.930 & 0.914 & 2. 404 \\
\hline 6 & Colonic cancer & 2.680 & 1.057 & 1.690 & 1.097 & 1. 036 & 0.696 & 0.825 & 3. 249 \\
\hline 7 & Colonic cancer & 3.048 & 1.100 & 1.824 & 1.119 & 0.992 & 0.811 & 0.739 & 4.125 \\
\hline 8 & Colonic cancer & 1.705 & 0.914 & 1.350 & 1. 182 & 1. 053 & 0.838 & 0.826 & 2. 064 \\
\hline 9 & Rectal cancer & 1.890 & 0.998 & 1.747 & 0.843 & 0.981 & 0.870 & 0.855 & 2. 211 \\
\hline 10 & Rectal eancer & 2.564 & 1. 021 & 0.993 & 1.015 & 1. 048 & 1. 213 & 0.933 & 2. 748 \\
\hline
\end{tabular}

DR represents the grade and direction of the deviation of the morbid tissue from the respective control tissue. If the DR value is larger than 1.000 , it means an increase of the percentage value of the fatty acid in the morbid tissue as compared with that of the control tissue. If the $\mathrm{DR}$ value is less than 1.000 , it means a decrease of the percentage value of the fatty acid in the morbid tissue as compared with that of the control tissue.

Fatty acid composition of the total lipid. The average values obtained from 12 cases of cancer and 6 cases of adenomatous polyp are shown in Table 3 . There were no significant differences between the cases of cancer and adenomatous polyp of the large intestine.

Fatty acid composition of phospholipids. The DR values in 10 cases of cancer are shown in Table 4, and the DR values in 14 cases of adenomatous polyp in Table 5. The DR value of $\mathrm{C}_{\mathbf{1 4 : 0}}$ in the cancerous cases was $2.307 \pm 0.484$ and was remarkably larger than that of adenomatous polyp $(1.001 \pm 0.394)$. Also the DR value of $\mathrm{C}_{16: 1}$ in the cancerous cases was $1.633 \pm 0.400$, which was larger than that in the adenomatous polypous cases $(1.122 \pm 0.230)$. However, the DR value 
TABLE 5. The phospholipid fatty acid composition of colonic and rectal adenomatous polypous tissues in terms of deviation rate

\begin{tabular}{|c|c|c|c|c|c|c|c|c|c|}
\hline \multirow{2}{*}{$\begin{array}{l}\text { Case } \\
\text { No. }\end{array}$} & \multirow{2}{*}{ Tissues } & \multicolumn{5}{|c|}{ Deviation rate } & \multirow[b]{2}{*}{$\mathrm{C}_{18: 2}$} & \multirow[b]{2}{*}{$C_{20: 4}$} & \multirow{2}{*}{$\frac{\text { Ratio of DR }}{\mathrm{C}_{14: 0} / \mathrm{C}_{204}}$} \\
\hline & & $\mathrm{C}_{14: 0}$ & $\mathrm{C}_{16: 0}$ & $\mathrm{C}_{16: 1}$ & $\mathrm{C}_{18: 0}$ & $\mathrm{C}_{18: 1}$ & & & \\
\hline 1 & Rectal & 0.698 & 0.944 & 0.880 & 1. 216 & 0.999 & 1. 139 & 1.003 & 0.696 \\
\hline 2 & Rectal & 0.924 & 0.861 & 1.187 & 1. 506 & 0.940 & 0.956 & 0.917 & 1.008 \\
\hline 3 & Rectal & 0.697 & 0.983 & 0.872 & 1.094 & 0.825 & 1.079 & 1.235 & 0.564 \\
\hline 4 & Colonic & 1.393 & 1. 003 & 1. 298 & 0.994 & 0.871 & 1. 167 & 1.210 & 1. 151 \\
\hline 5 & Colonic & 1.667 & 1. 233 & 1.478 & 0.950 & 0.969 & 0.755 & 0.898 & 1.856 \\
\hline 6 & Colonic & 0.899 & 1. 132 & 0.893 & 1. 067 & 0.847 & 0.966 & 1.002 & 0.897 \\
\hline 7 & Colonic & 0.705 & 1. 131 & 1.015 & 0.697 & 0.921 & 0.877 & 1. 173 & 0.601 \\
\hline 8 & Colonic & 0.348 & 0.972 & 1.300 & 0.926 & 1. 188 & 1.070 & 0.885 & 0.393 \\
\hline 9 & Colonic & 1. 371 & 0.949 & 1. 028 & 1. 058 & 0.980 & 1. 142 & 0.893 & 1. 535 \\
\hline 10 & Colonic & 1.500 & 1. 336 & 1.412 & 1.284 & 0.981 & 1.023 & 0.956 & 1.569 \\
\hline 11 & Rectal & 1.110 & 0.935 & 0.959 & 0.910 & 0.972 & 0.996 & 0.841 & 1.320 \\
\hline 12 & Colonic & 0.597 & 0.807 & 0.909 & 0.856 & 1.227 & 0.944 & 0.902 & 0.662 \\
\hline 13 & Rectal & 1.208 & 1. 098 & 1. 594 & 0.983 & 0.825 & 1. 071 & 0.967 & 1. 249 \\
\hline 14 & Rectal & 0.592 & 0.980 & 0.865 & 0.943 & 1. 039 & 1. 169 & 0.862 & 0.687 \\
\hline 15 & Colonic & 0.733 & 1. 068 & 1. 215 & 0.911 & 1. 018 & 1.076 & 1.060 & 0.692 \\
\hline 16 & Colonic & 1.580 & 0.960 & 1. 043 & 1,125 & 0.966 & 0.957 & 1.249 & 1.265 \\
\hline
\end{tabular}

TABLE 6. The triglyceride fatty acid composition of colonic, caecal and rectal lesions in terms of deviation rate

\begin{tabular}{|c|c|c|c|c|c|c|c|}
\hline \multirow{2}{*}{$\begin{array}{l}\text { Case } \\
\text { No. }\end{array}$} & \multirow{2}{*}{ Diagnosis } & \multicolumn{6}{|c|}{ Deviation rate } \\
\hline & & $\mathrm{C}_{14: 0}$ & $\mathrm{C}_{16: 0}$ & $\mathrm{C}_{16: 1}$ & $\mathrm{C}_{18: 0}$ & $\mathrm{C}_{18: 1}$ & $\mathrm{C}_{18: 2}$ \\
\hline 1 & Rectal cancer & 1. 120 & 0.935 & 0.719 & 2.425 & 1.050 & 0.590 \\
\hline 2 & Rectal cancer & 1.054 & 0.972 & 1.698 & 0.990 & 1.054 & 0.519 \\
\hline 3 & Caecal cancer & 1.044 & 1.179 & 0.687 & 3.406 & 0.816 & 0.882 \\
\hline 4 & Colonic cancer & 0.431 & 1. 027 & 0.649 & 3.127 & 0.939 & 0.806 \\
\hline 5 & Rectal cancer & 0.506 & 0.944 & 0.826 & 1.623 & 0.975 & 0.877 \\
\hline 6 & Colonic cancer & 1. 062 & 0.822 & 0.658 & 1.671 & 1.054 & 0.652 \\
\hline 7 & Colonic cancer & 0.638 & 0.731 & 0.798 & 0.878 & 1.397 & 1.229 \\
\hline 8 & Colonic cancer & 1.552 & 1. 088 & 0.839 & 1.263 & 0.930 & 0.781 \\
\hline 9 & Rectal cancer & 0.453 & 0.664 & 0.604 & 0.984 & 1. 462 & 1.672 \\
\hline 10 & Rectal cancer & 1.044 & 1. 114 & 0.696 & 2.382 & 0.797 & 0.714 \\
\hline 1 & Colonic adenomatous polyp & 1.443 & 0.997 & 1.066 & 1. 771 & 0.772 & 0.976 \\
\hline 2 & Rectal adenomatous polyp & 1.446 & 1.343 & 1.010 & 2. 638 & 0.648 & 0.611 \\
\hline 3 & Rectal adenomatous polyp & 0.971 & 1.115 & 0.732 & 3.546 & 0.820 & 0.773 \\
\hline 4 & Colonic adenomatous polyp & 0.972 & 1.066 & 0.737 & 2. 188 & 0.659 & 0.833 \\
\hline 5 & Colonic adenomatous polyp & 0.814 & 1. 347 & 0.766 & 2.089 & 0.696 & 0.563 \\
\hline 6 & Colonic adenomatous polyp & 1. 309 & 1.467 & 1.074 & 2.330 & 0.553 & 0.366 \\
\hline 7 & Colonic adenomatous polyp & 1. 661 & 1.010 & 1.032 & 0.858 & 0.897 & 1.460 \\
\hline 8 & Colonic adenomatous polyp & 2. 179 & 0.710 & 1.044 & 2. 104 & 0.699 & 0.986 \\
\hline 9 & Colonic adenomatous polyp & 0.959 & 1. 227 & 0.602 & 2. 136 & 0.793 & 1.043 \\
\hline 10 & Colonic adenomatous polyp & 1.849 & 1. 428 & 0.862 & 2.200 & 0.572 & 0.391 \\
\hline 11 & Rectal adenomatous polyp & 1.986 & 1.107 & 1.320 & 1.831 & 0.714 & 0.489 \\
\hline 12 & Rectal adenomatous polyp & 0.711 & 1.035 & 0.862 & 1. 167 & 0.945 & 1.227 \\
\hline 13 & Rectal adenomatous polyp & 1. 023 & 1. 034 & 0.546 & 4. 591 & 0.910 & 0.890 \\
\hline 14 & Colonic adenomatous polyp & 0.726 & 0.792 & 0.879 & 0.805 & 1. 138 & 1.367 \\
\hline
\end{tabular}

of $\mathrm{C}_{20: 4}$ in the cancerous cases was $0.762 \pm 0.122$, and showed the most remarkable decrease as compared with that of adenomatous polyp (1.003 \pm 0.135$)$. Thus, the ratio of the $D R$ value of $\mathrm{C}_{14: 0}$ to that of $\mathrm{C}_{20: 4}$ was calculated in each case, in order 
to visualize the difference between cancer and adenomatous polyp in the large intestine. As shown in Tables 4 and 5, a distinct difference between the human cancerous and adenomatous polypous tissues was recognized.

Fatty acid composition of triglycerides. The DR values in 10 cases of cancer and 14 cases of adenomatous polyp are shown in Table 6 . The DR value of $\mathrm{C}_{14: 0}$ in the cancerous cases was $0.890 \pm 0.121$, which was smaller than that of adenomatous polyp $(1.289 \pm 0.465)$. Furthermore, the $\mathrm{DR}$ value of $\mathrm{C}_{18: 1}$ in the cases of adenomatous polyp was $0.773 \pm 0.154$, and showed a remarkable decrease as compared with that of the cancerous cases $(1.047 \pm 0.210)$.

\section{Discussion}

As pointed out previously, it is important in the study of the human morbid tissues to consider what kind of tissue is the most suitable for the control tissue. We believe that it would be the best way to use the respective normal tissue surrounding the lesion, because the nature of the mother tissue of the morbid tissue would certainly be similar to or the same as that of the respective normal tissue surrounding the lesion. This is the most important point that we have to take care when we study the human morbid tissues from the standpoint of lipid chemistry, because the lipid of human tissues might be different among individuals owing to nutritional differences. This is a condition entirely different from the animal experiments which were already reported by other authors (Veerkamp et al. 1961; Figard and Greenberg 1962; Gray 1963).

For the convenience of comparing the values of the morbid tissues with those of the respective control tissue with respect to the fatty acid composition of each lipid fraction, the idea of the deviation rate was used in this report.

The fatty acid content of the total lipid in the morbid tissues was decreased in $71 \%$ of cancerous cases, but was increased in $80 \%$ of adenomatous polypous cases, compared with the respective control tissues.

The fatty acid content of phospholipid in the morbid tissues was decreased in $60 \%$ of cancerous cases, but was increased in $71 \%$ of adenomatous polypous cases, compared with the respective control tissues.

The fatty acid content of triglyceride in the morbid tissues was decreased in $100 \%$ of cancerous cases and in $93 \%$ of adenomatous polypous cases when compared with the respective control tissues. This phenomenon is very interesting, because it would be related to the neoplastic growth in the large intestine. One possibility to account for this observation is the increased utilization of triglyceride in rapidly proliferating cancerous tissues, since the triglyceride has been thought to be one of the main energy sources in the tissue growth. Another possibility would be a depressed biosynthesis of triglyceride in cancerous tissues. Recently, we recognized a considerably depressed biosynthesis of triglyceride in the liver of lymphoma bearing mice. Two possibilities mentioned above would also be worth considering for adenomatous polypous tissues. At present, the 
true mechanism of this phenomenon is not clear.

The ratios of the phospholipid fatty acid content to the triglyceride fatty acid content in the neoplastic tissues were always higher than those of the respective control tissue in both cancer and adenomatous polyp as shown in Tables 1 and 2. This phenomenon would be one of the biochemical distinctive features of the tissue proliferation which has been shown to be associated with a tendency of decrease in the fatty acid content of triglyceride in the morbid tissues. As can be seen in Table 2, there was one exceptional case of adenomatous polyp in which the triglyceride fatty acid content in the morbid tissue was larger than that of the respective control tissue. This may not be surprising because the adenomatous polypous cases studied may contain various stages of tissue growth (Deschner and Lipkin 1975).

As for the fatty acid composition of the phospholipid, the $D R$ value of $C_{14: 0}$ in the cancerous tissues was remarkably increased when compared with that of the adenomatous polypous tissues $(p<0.01)$. Conversely, the $D R$ value of $C_{20: 4}$ in the cancerous cases was remarkably decreased when compared with that of the adenomatous polypous tissues $(p<0.01)$. Furthermore, when the ratio of the $D R$ value of $C_{14: 0}$ to the $D R$ value of $C_{20: 4}$ was calculated in each case, the values of the ratio was distributed between 2.064 and 4.125 in 10 cancerous cases, and between 0.393 and 1.856 in 16 cases of adenomatous polyp. Namely, if we calculate this ratio, it would be possible to distinguish between cancer and adenomatous polyp in the large intestine. Such a qualitative alteration of phospholipids in malignant neoplastic tissues is of great interest, since it may be useful to clarify the characteristics of cancerous cell walls.

As for the fatty acid composition of triglyceride, the $D R$ value of $C_{14: 0}$ in the cancerous cases was lower than that of the adenomatous polypous cases $(p<0.05)$. Conversely, the $\mathrm{DR}$ value of $\mathrm{C}_{18: 1}$ in the adenomatous polypous cases was decreased most remarkably, when compared with that of the cancerous cases $(p<0.01)$.

Naturally, the discussion mentioned above should be limited to the lesion of the human large intestine, but the present study suggests that the lipid-chemical approach could be applied to other organs to clarify some characteristics of malignant growth in other organs.

\section{References}

1) Deschner, E.E. \& Lipkin, M. (1975) Proliferative patterns in colonic mucosa in familial polyposis. Cancer, 35, 413-418.

2) Figard, P.H. \& Greenberg, D.M. (1962) The phosphatides of some mouse ascites tumors and rat hepatomas. Cancer Res, 22, 361-367.

3) Folch, J., Lees, M. \& Sloane Stanley, G.H. (1957) A simple method for the isolation and purification of total lipides from animal tissues. J. biol. Chem., 226, 497-509.

4) Gray, G.M. (1963) The lipid composition of tumour cells. Biochem. J., 86, 350-357.

5) Morson, B.C. (1962) Some peculiarities in the histology of intestinal polyps. Dis.

6) Nakazawa, I., Yamagata, S. \& Watanabe, H. (1973) Lipid-chemical differences between human cancerous and adenomatous polypous tissues in the large intestine. Tohoku J. exp. Med., 110, 23-32. 
7) Nakazawa, I., Yamagata, S. \& Watanabe, H. (1974) Lipid-chemical differences between cancerous and adenomatous polypous tissues in the human large intestine. In: Abstracts of the 11th International Cancer Congress, Florence, Panels, p. 9.

8) Veerkamp, J.H., Mulder, I. \& Deenen, L.L.M. (1961) Comparative studies on the phosphatides of normal rat liver and primary hepatoma. Z. Krebsforsch., 64, 137-148.

9) Vogel, W.C., Doizaki, W.M. \& Zieve, L. (1962) Rapid thin-layer chromatographic separation of phospholipids and neutral lipids of serum. J. Lipid Res., 3, 138-140.

10) Watanabe, H., Narasaka, T., Miura, K. \& Yamagata, S. (1972) An improved fibercolonoscope and its application to the colonic diseases. In: Proceeding of the 2nd World Congress of Gastrointestinal Endoscopy, Piccin Medical Book, Padua and London, pp. 557-563. 